\title{
Fabrication and properties of ultra highly porous cordierite with oriented micrometer-sized cylindrical pores by gelation and freezing method
}

\author{
Manabu FUKUSHIMA, ${ }^{\dagger}$ Masayuki NAKATA and Yu-ichi YOSHIZAWA \\ Advanced Manufacturing Research Institute, National Institute of Advanced Industrial Science and Technology (AIST), \\ 2266-98, Shimo-Shidami, Moriyama-ku, Nagoya 463-8560
}

Cordierite with ultra high porosity and oriented micrometer-sized cylindrical pores was prepared using a novel gelation-freezing method. Gelatin (used as the gelation agent), water (for formation of pores), and cordierite powder were mixed and cooled at $7^{\circ} \mathrm{C}$. The obtained gel was frozen at -20 or $-50^{\circ} \mathrm{C}$, was dried using a freeze drier under vacuum, and then degreased at $600^{\circ} \mathrm{C}$ and sintered at $1200-1400^{\circ} \mathrm{C}$ for $2 \mathrm{~h}$. The porosity was determined to be $93-79 \%$, and was dependent on the powder content in the gel and the sintering temperature. SEM observations of the sintered body showed the microstructure of orderly unidirectionally oriented micrometer-sized cylindrical cells. The cell size was $25-235 \mu \mathrm{m}$, and these values were confirmed by the freezing temperature. The numbers of cells for the samples frozen at -20 and $-50^{\circ} \mathrm{C}$ were $20-30$ and $500-1500 \mathrm{cells} / \mathrm{mm}^{2}$, respectively, in the cross sections of the sintered bodies. The resulting porous cordierite with a total porosity of $87 \%$ showed a compressive strength of $4 \mathrm{MPa}$; this was thought to be due to the tight packing during freezing. The porosity, number of cells and strength were significantly higher than the reported values for other porous cordierite ceramics.

(02008 The Ceramic Society of Japan. All rights reserved.

Key-words : Gelation, Freezing, Casting, Cordierite, Filter, Porosity and pore size

[Received October 15, 2008; Accepted November 20, 2008]

\section{Introduction}

Porous cordierite has attracted much attention due to its low thermal expansion coefficient, excellent thermal shock and chemical stability at elevated temperatures, as well as its low cost. ${ }^{1)-3)}$ It has also been widely utilized as filters, catalyst supports and membrane supports. For these applications, porosity is one of most important factors, because high porosity is expected to result in high permeability and effective filtration due to the low-pressure drop.

A number of processes, such as the addition of pore-forming agents and foam and gel-casting routes, have been employed in attempts to raise the porosity. ${ }^{4)-8)}$ Our previous research has focused on the preparation of porous ceramic by gelation of slurry and freezing. ${ }^{9), 10)}$ Its wet gel consisted of alumina dispersed polyethyleneimine (PEI) based gel, which was capable of retaining water. ${ }^{9), 10)}$ Ice crystals were observed to form in the gels upon freezing. In an effort to prevent cracks during drying, ice was sublimated and removed by vacuum freeze-drying without shrinkage at a moderate temperature. Finally, the green body was sintered and porous ceramic was obtained. This process does not require large amount of organic components and is an eco-friendly method in which the pores are derived from ice crystals.

The porous ceramic prepared from freezing route has been previously reported by other authors. In a number of these reports, a water-based slurry or alkoxide-derived gel such as silane was frozen to prepare the porous body. ${ }^{11-17)}$ Nishihara et al. showed the preparation of silica gel by using silane.

\footnotetext{
Corresponding author: M. Fukushima; E-mail: manabu-fukushima @ aist.go.jp
}

Moreover, they were able to obtain a surface area of $900 \mathrm{~m}^{2} / \mathrm{g} .{ }^{11), 12)}$ Ding et al. reported mullite with porosity around $90 \%$ from alkoxide. ${ }^{13)}$ On the other hand, Fukasawa et al. showed alumina with $40-80 \%$ porosity and silicon nitride with $50-70 \%$ porosity prepared from slurry. ${ }^{14)-17)}$ For these freeze-casting methods, high porosity for slurry-based process was not available due to the difficulty involved in handling the green body, whereas for the precursor solution process, the obtained material was limited by the type of precursor. These were problems to be overcome in the freeze-casting process.

Our previous gelation-freezing route ${ }^{9,10)}$ may solve the issues described above, in which handling of the green body is facile due to PEI, and the porous material can be prepared regardless of the type of starting powder. However, the obtained porosity was at most $70 \%$ due to the water retention ability of PEI gel. Thus, our previous works suggested that highly porous ceramic may be obtained by using a gel capable of retaining significant amounts of water, such as gelatin.

In the present work, we report the preparation of highly porous cordierite by the gelation-freezing method. The open porosity, cell size, microstructure and mechanical strength are also reported.

\section{Experimental}

Commercially available cordierite powder with an average particle size of $1.7 \mu \mathrm{m}$ was used as received (Marusu Glaze Co., Ltd., Aichi, Japan). The main impurities in the cordierite powder were 0.3 mass $\% \mathrm{Fe}_{2} \mathrm{O}_{3}, 0.2$ mass $\% \mathrm{CaO}$ and 0.2 mass $\% \mathrm{~K}_{2} \mathrm{O}$. The cordierite powder was mixed with a gelatin solution (Wako Pure Chemical Industries Ltd., Tokyo, Japan), which was solved with water around $50^{\circ} \mathrm{C}$. The mixing ratios of cordierite powder/ gelatin solution were 5/95 and 10/90 in volume, and these 
solutions are referred to as $\mathrm{C} 5$ and $\mathrm{C} 10$, respectively. The mixture was stirred using a planetary homogenizer (Thinky, type AR-250, Tokyo, Japan). The slurry was put into the centrifuge container and this centrifuge container was revolved while rotat-

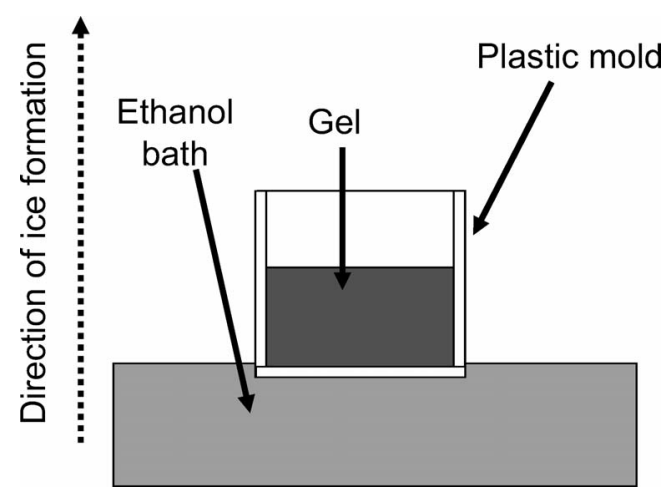

Fig. 1. Schematic illustration of freezing of gel.
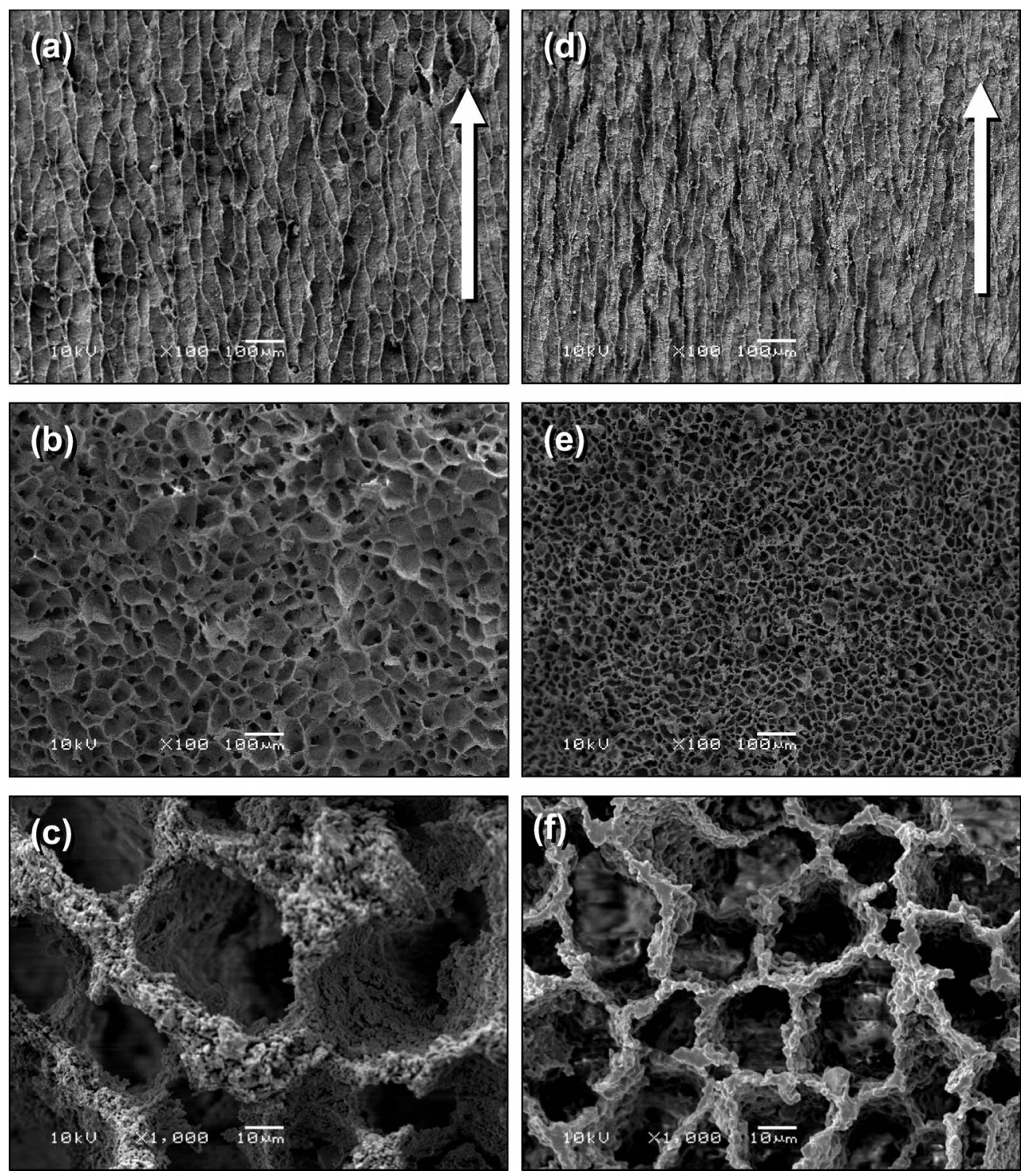

Fig. 3. SEM micrographs of fracture surfaces of the $\mathrm{C} 5$ specimen (frozen at $-50^{\circ} \mathrm{C}$ ) sintered at (a-c) 1200 and $(\mathrm{d}-\mathrm{f}) 1400^{\circ} \mathrm{C}$. 
either $-50^{\circ} \mathrm{C}$ or $-20^{\circ} \mathrm{C}$.

A schematic illustration of the freezing of the gel is shown in Fig. 1. After the ice crystals formed, the mold was removed. The sublimation of ice crystals in the iced gel was carried out under vacuum in a freeze drier at $10-35^{\circ} \mathrm{C}$ for $24 \mathrm{~h}$ (Tokyo Rikakikai Co., Ltd., Model FDU-2100, Tokyo, Japan), and green bodies were obtained. The green body was degreased at $600^{\circ} \mathrm{C}$ for $2 \mathrm{~h}$ and sintered at $1200-1400^{\circ} \mathrm{C}$ with a heating rate of $5^{\circ} \mathrm{C} / \mathrm{min}$ for $2 \mathrm{~h}$.

Open porosity and bulk density were determined using the Archimedes method, in which distilled water was used as the liquid medium. The compressive strength of samples with a diameter of $\phi 11 \mathrm{~mm}$ and a height of $10 \mathrm{~mm}$ was measured using the universal testing machine (MTS Systems Corporation, Sintech 10/GL, Minnesota, USA) with a cross-head speed of 0.5 $\mathrm{mm} / \mathrm{min}$. Cylindrical specimens were loaded on the top and bottom surfaces. The load was parallel to freezing direction. A minimum of five samples was tested to obtain the average strength. The microstructures of fractured or polished surfaces were observed by scanning electron microscopy (JEOL Ltd., Model JSM-5600, Tokyo, Japan). The cell size and number of cells were measured using the intercept method or image analysis of the SEM micrographs was carried out, and around 400 micrographs and more than 11000 cells were investigated for characterization.

\section{Results and discussion}

Figure 2 shows the porosities of the porous cordierite specimens (frozen at $-50^{\circ} \mathrm{C}$ ) as a function of the sintering temperature. The effect of sintering temperature on the porosity was observed. The porosity of porous cordierite was observed to decrease with increasing sintering temperatures. The porosities of the C5 and C10 were found to decrease from 93 to $87 \%$ and from 88 to $79 \%$, respectively, upon sintering at $1200-1400^{\circ} \mathrm{C}$.
Further, the porosities were also observed to be directly affected by the slurry concentration. The porosity of C5 was found to be 5-8\% higher than that of $\mathrm{C} 10$ for all sintering temperatures. Thus, porosity could be varied by sintering temperature and slurry concentration. On the other hand, closed porosities for all samples were less than $1.0 \%$. This suggests that water almost completely converted pores that were interconnected.

Figure 3 shows the SEM micrographs of fracture surfaces of the C5 sample sintered at $(\mathrm{a}-\mathrm{c}) 1200$ and $(\mathrm{d}-\mathrm{f}) 1400^{\circ} \mathrm{C}$; in parallel (a and $\mathrm{d}$ ) with the freezing $\left(-50^{\circ} \mathrm{C}\right)$ direction as indicated by the arrows and in the perpendicular direction (b-c and e-f). Highly oriented cells were found to form parallel to the freezing direction, and the observed cells were interconnected and entangled. These pores are thought to be formed due to the growing ice crystal. This channeled structure existed unidirectionally in an entire sintered body from the bottom of the sintered body toward the top, and any dendritic structure formed due to crystal growth of the ice was not observed, which was well-known in the freeze casting route of water based slurry (without organic). ${ }^{14)-17)}$ The cell-shaped pores were observed perpendicular to the crystal growth. These observed pores were honeycomb-shaped with micrometer-sized cells, in which the shape was obviously different from that of foam, pore-forming agents and those observed in other freeze-casting routes. ${ }^{4), 5), 13)-18 \text { ) }}$ This cylindrical structure was observed throughout the porous body, with the exception of the side and bottom of the porous body, in which surfaces were denser due to contact with the mold. The average diameters of the cells in the C5 sintered at 1200 and $1400^{\circ} \mathrm{C}$ were 46 and $25 \mu \mathrm{m}$, respectively. The diameters of the cells decreased with increasing sintering temperature due to shrinkage during sintering. The number of cells in the cross section was about 500 and 1500 cells $/ \mathrm{mm}^{2}$ for the C5 sintered at 1200 and $1400^{\circ} \mathrm{C}$, respectively. In addition, the thickness of the cell wall of the C5 sintered at 1200 and $1400^{\circ} \mathrm{C}$ were
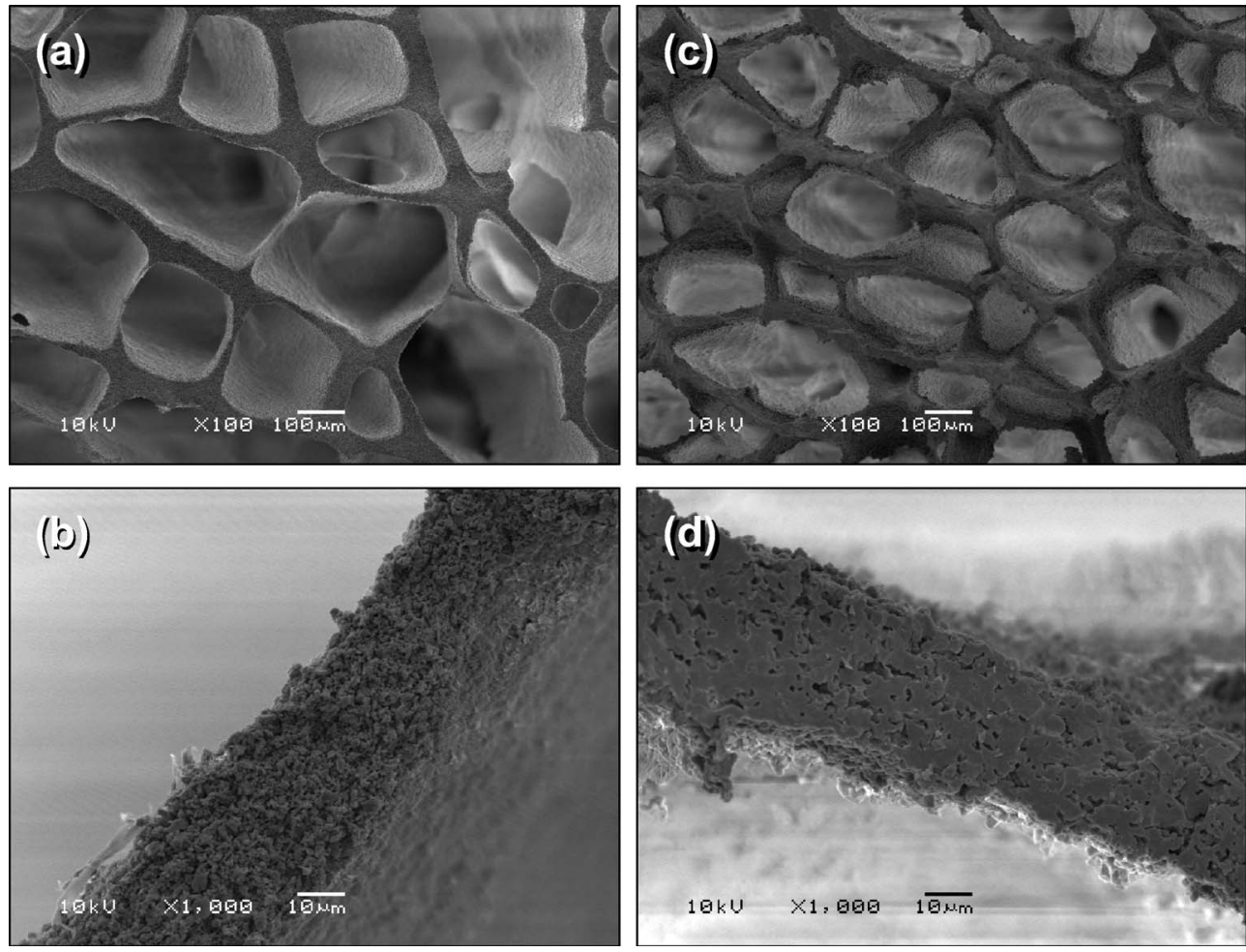

Fig. 4. SEM micrographs of the $\mathrm{C} 10$ specimen (frozen at $-20^{\circ} \mathrm{C}$ ) sintered at (a-b) 1200 and (c-d) $1400^{\circ} \mathrm{C}$. 
observed to be 4.4 and $3.0 \mu \mathrm{m}$, respectively, based on micrographs at higher magnification. The cell thickness was observed to decrease with increased sintering temperature. In addition, dense walls in the cell were observed, as shown in Fig. 3(f). Moreover, the density of these walls was found to be dependent on the sintering temperature.

In an effort to observe the effect of freezing temperature on cell size, some gel samples $(\mathrm{C} 10)$ were frozen at $-20^{\circ} \mathrm{C}$ and sintered at either 1200 or $1400^{\circ} \mathrm{C}$. The porosity of these samples was $80-89 \%$ and decreased with increasing sintering temperature. These values were similar to those obtained with other samples prepared by freezing at $-50^{\circ} \mathrm{C}$ (see Fig. 2). Figure 4 shows the SEM micrographs of the $\mathrm{C} 10$ samples sintered at (a-b) 1200 and (c-d) $1400^{\circ} \mathrm{C}$, which were formed perpendicular to the freezing $\left(-20^{\circ} \mathrm{C}\right)$ direction. An interconnected pore channel without a dendritic structure was observed throughout the samples. Furthermore, the cell size was clearly larger than those observed in Fig. 3. When a gelatin-based gel was frozen at a higher temperature, the size of the ice crystal was found to be larger than that for the sample prepared at a lower temperature. ${ }^{19)}$ The average diameters of the cells sintered at 1200 and $1400^{\circ} \mathrm{C}$ were 235 and $182 \mu \mathrm{m}$, respectively. The number of cells in the cross section was about 20 and 30 cells $/ \mathrm{mm}^{2}$, and the thicknesses of the cell walls were 44 and $29 \mu \mathrm{m}$ for the C10 sintered at 1200 and $1400^{\circ} \mathrm{C}$, respectively.

Typical properties of highly porous cordierite are summarized as follows. Song et al. reported a porosity of $74 \%$, cell size around $13 \mu \mathrm{m}$ and compressive strength of $4.3 \mathrm{MPa}$ with cells of similar size and porosity to those used in the present work. Senguttuvan showed a porosity of $83 \%$, cell size around 20-40 $\mu \mathrm{m}$ and compressive strength of $0.6 \mathrm{MPa}$. The compressive strength of the $\mathrm{C} 5$ sample (frozen at $-50^{\circ} \mathrm{C}$ and sintered at $1400^{\circ} \mathrm{C}$ ) with a total porosity of $86.8 \%$ and cell size of $25 \mu \mathrm{m}$ was $4.1 \mathrm{MPa}$, which was higher than that obtained by other methods, regardless of the higher porosity. This is thought to be due to the packing density of powder. A number of works on freeze-casting suggested that the raw powder was highly packed upon freezing. ${ }^{18)}$ Araki reported that porous alumina with $41 \%$ porosity could be prepared by freezing a slurry with camphene (freezing means solidification at room temperature), and alumina particles could be packed by dendritic formation upon solidification of camphene. In Figs. 3(a) and (d), particles appear to be pushed aside along the direction of the growing ice crystal, where cells are interconnected or entangled. When an ice crystal is formed (separated from gel), the particles in the remaining gel are concentrated due to removing of water. In addition, the particles are compacted by the volume increase upon conversion from water to ice. In fact, dense cell walls in the sintered body

Table 1. Typical Properties of Highly Porous Cordierite

\begin{tabular}{lcc}
\hline \multirow{2}{*}{ Property } & \multicolumn{1}{c}{$\mathrm{C} 5$} & $\mathrm{C} 10$ \\
\cline { 2 - 3 } & freezing at $-50^{\circ} \mathrm{C}$ & freezing at $-20^{\circ} \mathrm{C}$ \\
\hline Relative density & $86.8 \%$ & $80.0 \%$ \\
Open porosity & $85.9 \%$ & $79.0 \%$ \\
Closed porosity & $0.9 \%$ & $1.0 \%$ \\
Cell size & $25 \mu \mathrm{m}$ & $182 \mu \mathrm{m}$ \\
Cell thickness & $3 \mu \mathrm{m}$ & $29 \mu \mathrm{m}$ \\
Cell number & 1500 cells $/ \mathrm{mm}^{2}$ & 30 cells $/ \mathrm{mm}^{2}$ \\
\hline
\end{tabular}

were observed in high magnification micrographs (Figs. 3(c)-(f) and Figs. 4(b)-(d)). This observation strongly supports the suggestion made about the particle concentration and packing described above.

\section{Conclusions}

Cordierite with ultra high porosity (above $80 \%$ ) was prepared using a novel gelation-freezing method with gelatin gel at various powder concentrations. This unique technique could provide oriented micrometer-sized cylindrical pores. The cells formed honeycomb-like shapes and the pore size could be within a range of $25-235 \mu \mathrm{m}$ by varying the freezing temperature. The cells were surrounded by walls with thicknesses ranging from 3-44 $\mu \mathrm{m}$ and an average number of cells ranging from $20-1500$ per $\mathrm{mm}^{2}$. The resulting porous cordierite with around $87 \%$ total porosity showed a high compressive strength of $4 \mathrm{MPa}$, which was significantly higher than the reported value for other porous cordierites. This novel method is thought to be a potential process for a number of applications such as filters and catalyst supports.

Acknowledgement We thank Mr. Osamu CHUJO at AIST for critical comments on casting and freezing.

\section{References}

1) M. E. Milberg and H. D. Blair, J. Am. Ceram. Soc., 60, 372-373 (1977).

2) D. L. Evans, G. R. Fischer, J. E. Geiger and F. W. Martin, J. Am. Ceram. Soc., 63, 629-634 (1980).

3) S. S. V. S. S. Vepa and A. M. Umarji, J. Am. Ceram. Soc., 76, 1873-1876 (1993).

4) D.-H. Jang, Y.-W. Kim and H.-D. Kim, J. Ceram. Soc. Japan, 115, 52-58 (2007).

5) I.-H. Song, M.-J. Kim, H.-D. Kim and Y.-W. Kim, Scripta Materialia, 54, 1521-1525 (2006).

6) J. H. She and T. Ohji, Mater. Chem. Phys., 80[3], 610-614 (2003).

7) H. Schmidt, D. Koch, G. Grathwohl and P. Colombo, J. Am. Ceram. Soc., 84, 2252-2255 (2001).

8) S. Bhattacharjee, L. Besra and B. P. Singh, J. Eur. Ceram. Soc., 27, 47-52 (2007).

9) M. Nakata, K. Tanihata, S. Yamaguchi and K. Suganuma, $J$. Ceram. Soc. Japan, 113, 712-715 (2005).

10) M. Nakata, M. Fukushima and Y. Yoshizawa, Ceram. Eng. Sci. Proc., 28[7], 139-144 (2008)

11) S. R. Mukai, H. Nishihara and H. Tamon, Microporous and Mesoporous Mater., 63, 43-51 (2003).

12) H. Nishihara, S. R. Mukai, D. Yamashita and H. Tamon, Chem. Mater., 17, 683-689 (2005).

13) S. Ding, Y.-P. Zeng and D. Jiang, J. Am. Ceram. Soc., 90, 2276-2279 (2007)

14) T. Fukasawa, Z.-Y. Deng, M. Ando and T. Ohji, J. Ceram. Soc. Japan, 109, 1035-1038 (2001).

15) T. Fukasawa, M. Ando and T. Ohji, J. Ceram. Soc. Japan, 110, 627-631 (2002).

16) T. Fukasawa, M. Ando, T. Ohji and S. Kanzaki, J. Am. Ceram. Soc., 84, 230-232 (2001).

17) T. Fukasawa, Z.-Y. Deng, M. Ando, T. Ohji and S. Kanzaki, J. Am. Ceram. Soc., 85, 2151-2155 (2002).

18) K. Araki and and John W. Halloran, J. Am. Ceram. Soc., 88, 1108-1114 (2005).

19) S. Ueno, R. Shirakashi, G. Do, Y. Sagara, K. Kudoh and T. Higuchi, Trans. of the JSRAE, 21, 337-344 (2004) [in Japanese]. 